\title{
INDIVIDUAL RIGHTS AND COLLECTIVE AGENTS: THE ROLE OF OLD AND NEW WORKPLACE INSTITUTIONS IN THE REGULATION OF LABOR MARKETS?
}

\author{
David Weil \\ Working Paper 9565 \\ http://www.nber.org/papers/w9565 \\ NATIONAL BUREAU OF ECONOMIC RESEARCH \\ 1050 Massachusetts Avenue \\ Cambridge, MA 02138 \\ March 2003
}

The views expressed herein are those of the authors and not necessarily those of the National Bureau of Economic Research.

(C2003 by David Weil. All rights reserved. Short sections of text not to exceed two paragraphs, may be quoted without explicit permission provided that full credit including Cnotice, is given to the source. 
Individual Rights and Collective Agents: The Role of Old and New Workplace Institution in the Regulation of Labor Markets

David Weil

NBER Working Paper No. 9565

March 2003

JEL No. J58, J68, J71, L51, K31

\section{ABSTRACT}

Implementation of workplace policies--whether through enforcement of laws or administration of programs--raises the question of the interaction between institutions created to carry out laws and the activities of workplace based agents that directly (e.g. unions) or indirectly (e.g. insurance companies) represent the interests of workers. This paper argues that there are two distinctive roles required for agents in the implementation of workplace policies. First, the agent must somehow help solve the public goods problem inherent in workplace regulation. Second, the agent must be able to reduce the marginal cost of exercising rights conferred to workers that are an important feature of most regulatory programs. This article examines these issues in regard to implementing workplace policies in the U.S. and analyzes the comparative effectiveness of different workplace agents- from labor unions to alternative dispute resolution systems- in fulfilling these roles.

\section{David Weil}

Taubman Center T-310

John F. Kennedy School of Government

Harvard University

Cambridge, MA 02138

David_Weil@ksg.harvard.edu

and

Boston University

School of Management

595 Commonwealth Avenue, Room 520A

Boston, MA 02215

davweil@bu.edu 


\section{Labor Market Institutions and the Regulation of Labor Markets}

The Committee recognizes that accomplishment of the purposes of this bill cannot be totally achieved without the fullest cooperation of affected employees.

-Senate Report No. 91-1292, 91 ${ }^{\text {st }}$ Congress, 2d. Session (October 6, 1970), p. 10.

So concluded members of the Senate in drafting the Occupational Safety and Health Act of 1970.

Despite the fact that the new Act created an extensive government enforcement system charged with improving workplace safety and health, the architects of OSHA recognized the centrality of workers to its implementation. The same might be said for a gamut of federal and state labor market regulation from the Fair Labor Standards Act of 1938 to the Family Medical Leave Act of 1993 to state workers compensation and unemployment benefit systems.

As representatives of individual employees, labor market institutions can affect the process workplace regulation in two very different ways. First, they can affect the political process in passing legislation and through executive agencies in promulgating regulations-that is, the enactment of labor policies. Second, they can affect the way that those laws and regulations are enforced or administered—-that is the implementation of laws.

There is a significant literature on the role of interest groups in political processes that can inform the specific question of what alternative institutions might play the role of "employee lobbies" in the enactment of workplace policies. Although the specific constellation of factors that underlie political coalitions around employment issues differ from those underlying other public policy issues, the theoretical notions bounding the creation of such coalitions have parallels with those in surrounding other areas of policy concern. ${ }^{1}$ I therefore do not focus on the role for new labor market intermediaries in the realm of policy enactment here. 
Implementation of workplace regulations arises either from the enforcement of standards created by that legislation or through the administration of programs created by legislation. For example, the federal Davis-Bacon Act that establishes floors for wages in the construction industry is implemented by enforcement actions that either directly or through deterrence effects indirectly raise the wages paid by construction companies to the "prevailing wage" set for that craft in a geographic market. Workers compensation legislation is implemented via administrative activities in two ways: first through the incentive effect provided by experience rating of employers covered by the system on safety policies and second by the filing of claims by workers injured on the job.

Implementation--whether through enforcement or administration-raises the question of the interaction between institutions created by labor policies to carry out laws and the activities of workplace based institutions that directly (e.g. unions) or indirectly (e.g. insurance companies) represent the interests of workers. To examine the need for alternative workplace institutions in this area of labor market activity requires one to establish what role institutions-regardless of form - play in the first place. It then requires one to examine the relative abilities of different types of institutions to play these roles.

This paper argues that there are two distinctive roles required for agents in the implementation of workplace policies. First, the agent must somehow help solve the public goods problem inherent in workplace regulation. Second, the agent must be able to reduce the marginal cost of exercising rights conferred to workers that are an important feature of most regulatory programs. One of the major costs in this regard is that of employer discrimination arising from exercise of those rights. Although a variety of institutions may be capable of stepping into the fray and serving as agents in the enactment of legislation, the roles required for 
implementation are more difficult to embody in a labor market agent. Laying out the theoretical requirements for such agents focuses attention on the features of "emerging labor market institutions" most important to the implementation of workplace policies.

This chapter begins with a discussion of federal labor regulations in the U.S. and the roles they establish for workers through the provision of individually-based worker rights. It then presents a model concerning the decision by workers to exercise those rights. Based on insights from the model, it analyzes the requirements of workplace institutions in fulfilling those roles. The third section evaluates a variety of labor market institutions--beginning with labor unions as a benchmark - that potentially serve the role as agents. Based on this evaluation, the paper concludes with a discussion of how policies might be adapted to foster agents better able to serve the two central roles of labor market intermediaries in implementing labor regulations.

\section{Individual Rights and the Need for Collective Agents}

\section{IIA. Federal regulations and worker rights}

Federal workplace regulations provide employees with important roles directly affecting the implementation of those statutes. Much of workplace regulation dating back to Fair Labor Standards Act (FLSA) of 1938 and going forward to the Family Medical Leave Act passed almost sixty years later provides workers with an opportunity to participate in one or more aspects of the regulatory process. Most important of those rights is that of triggering regulatory activity itself. Although the right to trigger inspections dates back to some of the earliest statelevel labor legislation (Common and Andrews 1936), regulations promulgated during the two most recent surges of workplace legislation / executive orders (in 1963-74 and 1986 - 1993) have increased the number of regulations providing workers with a right to initiate civil actions under 
such laws as Title VII, ADA, PPA, and WARN. This has resulted in an enormous increase in the number of cases filed under employment law, relative to other categories of litigation. ${ }^{2}$

Table 1 depicts a subset of these roles under Federal workplace regulations: the right to initiate an agency action and the right to pursue private action in courts either as the first step in seeking to change employer behavior or after administrative remedies have been exhausted. Most federal legislation also establishes reporting / disclosure requirements that seek to inform employees of their rights, employer duties; or employer performance under the statute (these are depicted in the final two columns of Table 1). In addition to these rights, many workplace statutes enumerate employee rights regarding participation in various stages of the regulatory process, such as by providing workers (or their designated representatives) with a right to accompany government officials during inspections (OSHA, MSHA), and to appeal decisions or participate in hearings arising from inspections (OSHA, MSHA, CWHSSA).

There is little reason to believe that workers uniformly exercise rights granted them under labor policies. Studies in several different areas indicate that the propensity to exercise rights varies along systematic lines across different groups. A number of empirical studies have shown different propensities for individuals to litigate civil claims (see, for example, Hoyman and Stallworth 1981, Shavell 1987). Other studies have documented factors affecting workers' use of grievance procedures in union and nonunion workplaces (Peterson (1992); Feuille and Delaney (1992 ); Chachere and Feuille (1993)). This literature suggests that factors related to the individual (sex, education, demographic background), the workplace environment (size, degree of conflict, management and union policies), and the specific grievance or civil problem involved affect under what circumstances individuals use their rights. Given the limitations of government resources towards enforcement, the conditions under which employees exercise their 
rights either to initiate suits or agency action fundamentally affect achievement of policy goals in the workplace. In a somewhat different vein, labor market programs like workers compensation and unemployment insurance require that workers initiate the process leading to the issuance of benefits provided by those programs.

\section{IIB. A Threshold Model of the Exercise of Individual Rights}

The degree to which individual employees exercise rights granted them under labor regulations can be expected to depend on the perceived benefits versus costs of exercising rights from the perspective of an individual worker. The benefits of exercising a right are a function of the impact of labor legislation on the outcome of concern to the worker. For example, initiating an OSHA inspection potentially improves working conditions for the worker by diminishing or removing the risk of an injury or illness. The greater the level of perceived risk faced by the worker, the more likely they are to initiate an inspection or otherwise seek to affect redress of the

problem. Similarly, the greater the divergence between the wages paid to workers and the wages that they are entitled to under the law (e.g. because of premium pay required for overtime), the more likely a worker is to exercise rights to initiate actions under the FLSA.

In order to ascertain the magnitude of these benefits, workers must acquire information on the current and legally permissible level of a regulated outcome. The costs of exercising rights are primarily a function of the costs of gathering this information. These are composed of costs associated with: (a) obtaining information regarding the existence of basic rights as well as the standards to which employers are held accountable ${ }^{3}$; (b) gathering information on the current state of workplace conditions - a particular problem if the risks are complex as in the case of safety and health (Viscusi 1983, Viscusi and O'Connor 1984); and (c) learning about the specific 
details of how the law is administered (e.g. the procedures to initiate a complaint inspection). In addition to information-related costs, workers face significant costs arising from potential employer retaliation (the economic losses associated with retaliatory reassignment or, in the extreme, being fired ${ }^{4}$ ) as well as the potential cost of job loss arising from the chance that compliance will force a firm to reduce employment in the long run.

The decision facing a worker on whether or not to exercise a right is represented diagrammatically in Figure 1. The horizontal axis, $X_{j}$ represents the difference between current workplace conditions (e.g. exposure to a health risk; actual wage rate for hours of work) and the regulatory standard for that workplace outcome for workplace $j$. The value of $X_{j}$ is defined where:

$X_{j}<0$ : If the current workplace provides conditions above permissible levels (i.e. the firm goes beyond compliance required by the standard);

$X_{j}=0$ : If the current workplace provides conditions equal to the required levels (i.e. the firm is exactly in compliance with the law);

$X_{j}>0$ : If the current workplace provides conditions below permissible levels (i.e. the firm is out compliance).

This means that as $X_{j}$ increases, a workplace falls further out of compliance with the regulatory requirement. In the case of health and safety regulations, this means that as $X_{j}$ increases, worker exposure to risk increasingly goes beyond the risk levels if workplaces complied with standards; for regulations related to compensation like FLSA or Davis-Bacon, this means that actual pay increasingly falls below that required under the statute. For a program like workers compensation, increases in $X_{j}$ imply that the earnings received by the injured worker diverge more and more from those he or she is entitled by the program. 
Given this definition of $X_{j}$, the figure presents two marginal benefit functions. The lower function $\left(\mathrm{MB}_{i}\right)$ represents the marginal worker $i$ in a workplace $j$ who has the highest individual preference for compliance with the regulatory standard. As such, this function represents the worker who will first exercise his or her statutory right in the workplace. I assume that the marginal benefit of exercising a right that moves the firm into greater compliance with the standard is positive and increasing in $X_{j}$.

Since a violation of a workplace standard typically affects many workers and is often associated with violations of other standards that might not directly affect the worker triggering the inspection, employee exercise of workplace rights displays positive externalities. Because of this, the marginal benefit for the workplace as a whole is always higher than that of the marginal worker for any $X_{\mathrm{j}}$. The upper marginal benefit function in Figure 1 represents workers at the workplace as a whole $\left(\mathrm{MB}_{j}\right)$, and reflects the vertical aggregation of benefits for all affected workers for any given state $X_{j}{ }^{5}$

Figure 1 first presents a simple case where the costs of exercising a right are invariant across the different levels of $X_{j}$ and the same for an individual worker as they are for the workplace as a whole (the upper line, where $\mathrm{MC}_{i}=\mathrm{MC}_{j}$ ). If rights are vested at the individual level, worker $i$ will choose to exercise the rights at the state of the workplace $X_{i}^{*}$ where $\mathrm{MB}_{i}=$ $\mathrm{MC}_{i}$. Given that the decision is made by the marginal worker with the greatest preference workplace conditions consonant with regulatory standards (i.e. the lowest tolerance for current conditions being out of compliance), $X_{i}^{*}$ represents the level of non-compliance that will trigger the exercise of rights for that workplace, when left to the decision of this "threshold" individual worker. 
Given the public good character of the benefits ensuing from the exercise of rights, $X_{i}^{*}$ is not optimal for the workplace as a whole, because the marginal worker decides only on the basis of his or her individual preference. Accounting for all workers in the workplace, the optimal threshold in Figure 1 is $X_{j}^{*}$, where $X_{i}^{*}>X_{j}^{*}$. That is, the exercise of right taken at the individual level leads to a "higher" threshold (i.e. current conditions being more out of compliance with standards) than the threshold that would prevail if the preferences of all workers were considered. Workplace rights therefore will be underutilized because the collective benefits arising from their action are not factored into the individual decision.

If the cost of exercising a right exhibits increasing returns to scale, such as because of efficiencies gained from collecting information at the workplace, or multi-workplace level, the divergence between threshold for an individual versus collective group of workers grow even further. Protections against discrimination for exercise of rights afforded by a method of collectively exercising rights may represent a second reason that the marginal cost of exercise may be far lower for a group of workers. In either case, this situation is depicted in Figure 1 as $\mathrm{MC}_{\mathrm{j}}$, the lower dotted horizontal line, which is below the marginal cost function faced by an individual. The collective threshold for exercise of rights now occurs at $X_{j}^{* *}$, arising in an even larger gap from the individual threshold for exercising the right, $X_{i}^{*}$.

Thus, the problem arising from the structure of workplace regulations is that if left to the individual worker, the threshold for exercise of rights lies above the threshold optimal from the workplace—and societal—level. In order to close this gap, one must surmount the problem of (1) aggregating preferences across workers and (2) reducing the marginal cost of exercise of those rights. 


\section{IIC. Workplace Agents and the Exercise of Rights}

A collective workplace agent can potentially solve the problem described above. It can do so first by internalizing the positive externality to workers arising from a claim as a representative of all workers in the unit. A workplace agent can also gather and disseminate information thereby lowering the cost of information acquisition faced by individuals. The specific elements required of such an agent are straightforward and flows from the threshold model in Figure 1:

1) Interests allied with workers--specifically an interest in representing the collective preferences of workers in regard to working conditions;

(2) A means of efficiently gathering and disseminating information on rights, administrative procedures, and the nature of workplace risks;

(3) A method of providing protection from employer discrimination against individual workers for their exercise of rights. ${ }^{6}$

The need for an agent to play these roles points to a conundrum embedded in many workplace regulations. Although many of the policies listed in Table 1 create rights focused on the individual worker, exercise of individually-based rights requires an agent operating in the collective interest.

The above discussion also raises a related issue often overlooked in examining workplace regulation. One cannot detach the role of "command and control" regulatory systems from the operation of labor market institutions, even where labor market intermediaries are not explicitly set out in the legislation as the explicit agent for implementation. It is often assumed that under traditional regulatory structures, the government alone acts as the agent of enforcement. Yet as 
the review of labor regulations and the threshold model indicates, implementing workplace policies includes a role for workers and in that way for labor market intermediaries. The fact that an important avenue for enforcement of those laws is the exercise of individual rights belies a more complex interaction built into the structure of regulatory systems.

\section{Alternative Labor Market Institutions}

\section{IIIA. Unions and the Enforcement of Labor Policies}

While a number of different arrangements can potentially satisfy the conditions for a workplace agent, labor unions potentially fulfill many of them through their basic agency functions. ${ }^{7}$ Specifically, unions act as purveyors of workplace-based public goods regarding labor policies both by internalizing the benefits relating to worker exercise of rights across workers in the unit and by lowering the costs of information acquisition.

As the elected representative of workers, a union has incentives to act on behalf of the collective interests of members in the bargaining unit. This means that a union will not base perceptions of the benefit of pursuing a claim under laws based on the preferences of an individual worker at the margin, but based on infra-marginal evaluations of those benefits. In facing this allocation problem, a union can vertically aggregate preferences for the "public goods" represented by workplace regulations, following the model of public goods seminally described in Samuelson (1955). ${ }^{8}$

Unions can efficiently gather and disseminate information on the existence of workplace laws and rights created by those laws. Unions provide this information formally through educational programs, in apprenticeship training, or through supplying educational materials. Informally, union leaders or staff can alert members of their rights where a problem or issue 
arises. Unions also provide information on the existence of specific underlying problems, particularly in the area of safety and health (see Viscusi 1983). This information may be collected and disseminated through formal programs or channels, or informally via the union structure or fellow workers.

Unions also offer individual workers assistance in the actual exercise of their rights. This may result from the operation of committees established under collective bargaining, as is common in safety and health or via the help of union staff who can trigger inspections, oversee pension fund investments, or assist members file unemployment claims. Most importantly, unions can substantially reduce the costs associated with potential employer discrimination by helping affected employees to use anti-discrimination provisions of the labor policies and providing this protection via collective bargaining agreements regulating dismissals. The formal protection offered by a collective agreement provides security unavailable in the vast majority of nonunion workplaces, even where a grievance procedure exists (Feuille and Delaney 1992).

Thus, if unions act on behalf of the collective preferences of the workers in the bargaining unit, they can be expected to induce greater usage of rights. This sets up a testable empirical hypothesis: Government labor market policies should be more fully implemented in unionized workplaces than in otherwise comparable nonunion workplaces.

This hypothesis can be tested by examining empirical studies of labor market regulations that have measured union / nonunion differences in implementation. Table 2 summarizes evidence of union impacts on both enforcement and compliance under a wide array of labor policies. It confirms the predicted presence of systematic differences between union versus nonunion enforcement and compliance outcomes across diverse labor regulations and workplace policies. This includes regulations dating back to early labor legislation like the Fair Labor 
Standards Act, where unions appreciably raise the probability of compliance with premium pay for overtime. Unions also increase an array of enforcement outcomes and compliance with health and safety standards under both OSHA and MSHA, as well as provisions of ERISA. Unions also raise enforcement and compliance under some of the newest labor policies such as the Worker Adjustment and Retraining Act (WARN), Americans with Disabilities Act (ADA), and the Family Medical Leave Act (FMLA). Finally, unions substantially increase the probability that workers will receive benefits that they are eligible for under the two major workplace programs administered at the state level: unemployment insurance and workers compensation. ${ }^{9}$ Thus, with the exception of their neutral impact on contract compliance reviews under EO 11246, empirical studies of labor market enforcement indicate that unions act as agents that assist employee exercise of rights.

This review suggests that unions seem capable of surmounting the problem of the divergence between individual and collective exercise of rights under many different regulatory policies. This provides a useful benchmark to compare other potential agents that might play this role in the absence of union presence at the workplace.

How do other labor market intermediaries stack up in solving the problem posed by the individual versus collective exercise of rights? We evaluate six potential intermediaries below, each evaluated along the same three dimensions developed in Section II. The following sections do not provide an exhaustive review of these mechanisms, many of which are discussed elsewhere in this volume. The intention instead is to examine each of the alternatives against the two dimensions described above and indicate the relative strengths and weaknesses of each. 
This provides an analytic backdrop for the other papers that look into some of these mechanisms in greater depth.

IIIB. National issue organizations / Legal service organizations

Christine Jolls (2000) describes the activities of national issue organizations that deal at least in part with employment law (e.g. ACLU; NAACP Legal Defense Fund; National Employment Law Project) and legal service organizations (primarily the organizations administered by the Legal Services Corporation, created by Congress in 1974) as alternative institutions that assist employees exercise their rights. The role of national issue and legal service organizations lie either in terms of their impact on the public goods problem or in lowering the costs of exercise of rights (including the costs arising from employer discrimination).

Both types of organizations can act on the public goods aspect of the problem to the extent that they can serve as an agent to aggregate preferences for collective actions or lead workers to do so. One obvious mechanism for legal organizations to do so is by undertaking class action suits on behalf of groups of workers. Illustrative of this role are several recent cases of legal organizations doing so on behalf of agricultural workers and apparel workers in regard to violations arising under the FLSA (citation).

What incentives and capacities do these organizations have to play this role? The evidence presented in Jolls suggests that the nature of funding for the two organizations creates incentives that lead both organizations away from the role of solving the workplace public goods problem. National interest organizations tend to focus on fundraising and involvement in high profile litigation focused on setting larger legal precedent. Legal service organizations, in contrast, tend to focus on specific cases that arise from individuals coming to those 
organizations. Thus, national interest organizations focus on "high profile, publicly-charged issues... [working on] a few influential cases" while legal service organizations "tend to work on many routine cases...” (pp. 30-31).

The different character of the subject matter of legal activities suggests a fundamental agency problem in both organizations that undermine them from playing a role analogous to that of labor unions in the workplace. National interest organizations act at least in part as agents of their principal sources of funding - private donors and foundations. Those parties seek to maximize their investment (donations / grants) in terms of public impact (or at least perceptions of public impact). This tends to push those organizations away from workplace-level interventions and towards cases involving major precedent and public controversy.

Legal service organizations, in contrast, are agents of their very different funding source, the U.S. Congress. Although Congress cannot be considered a principle with a single utility function, Jolls' evidence is consistent with a story that the long term coalition necessary to sustain funding is one where the median Congressional voter seeks to focus those organizations on the modest goal of lowering the cost faced by low income individuals in pursuing civil claims. The median Congressional voter however has historically rejected the notion that legal services should act as an agent for larger groupings of individuals. ${ }^{10}$ In this view, legal service organizations might lower the marginal cost of exercise of rights, but only on an ad hoc basis, driven by the individual worker decision to approach legal services for assistance in the first place. 


\section{IIIC. Other public interest organization}

There are many other public interest groups that have been organized to deal with the workplace issues, with less focus on legal assistance than the organizations studied by Jolls. These include "COSH" groups (Committees on Safety and Health) organized in a number of states focused on safety and health; disabled workers groups focused on issues of workers compensation, the Americans with Disabilities Act, and to a lesser extent OSHA; and groups focused on workplace regulations affecting low wage workers in specific industries (e.g. "sweatshop" problems in apparel; child labor problems in agriculture or retail). One activity of many of these groups is lobbying and participating in legislative and executive forums at the state- and federal-level. In this capacity, they attempt to affect either the enactment of laws / regulations or appropriations towards existing programs, as opposed to the implementation issues of central interest here (see Hersch 2000 for discussion of the role of new labor market institutions on legislative enactment).

However, a second set of activities pursued by these groups is direct worker assistance. In the 1970s, for example, many COSH groups formed in states to provide information and assistance to workers under OSHA. The intention of many of these groups was to provide workers-in particular nonunion workers—-with information regarding their rights under the newly passed act. A comparable group was formed for nonunion miners to assist them exercise rights under MSHA (McAteer 1985).

These groups tend to receive their donations from a mix of labor unions (a significant source of funding for $\mathrm{COSH}$ and disabled worker groups in particular), foundations, and small individual workers / donors. The importance of labor unions as a funding source as well as small donors (often those with a personal connection to the issue) tends to lessen the agency problem 
discussed in regard to either national interest or legal service organizations. This potentially leads to better alignment between the objectives of the groups and those of the workers they intend to assist. ${ }^{11}$

The main difficulty facing these groups is that they operate outside of the workplace, although one of their intentions is to help solve the public goods problem that exist within it. This limits their potential impact on the exercise of rights primarily to an informational rolethat is towards reducing the marginal costs of exercise of rights. However, even here their impact is modest: Their lack of presence at the work site means that they can have limited impact on the threat of discrimination arising from exercise of rights, perhaps the highest cost facing workers. It is noteworthy that COSH groups in many states have concentrated much of their efforts over time in their work in conjunction with unions and unionized workplaces, where they take advantage of an established agent (comparable to the effects of workplace committees described below). ${ }^{12}$

The threshold problem presented by workers compensation and unemployment insurance is somewhat different than that posed by OSHA or MSHA. Here, the public goods aspects of providing information and assistance regarding benefits are somewhat less than in regulatory programs (that is, the benefits provided by the program look less like public goods). The threshold problem therefore arises more from the difference between the marginal costs of disseminating information to workers on a collective versus individual basis. The potential for employer discrimination is also much less for these benefit programs, in part because the their financing (and therefore the potential costs to employers) is disconnected from the provision of benefits. As a result, the network of disabled worker organizations can potentially play a more fruitful role —outside of the workplace — in providing information on the availability of benefits 
and assistance in filing claims. Although alternative institutions potentially could assist workers in the area of unemployment insurance in a comparable way, there is an absence of a large network of such organizations in this realm. ${ }^{13}$

\section{IIID. Mandated Workplace Committees:}

A number of states mandate that employers establish workplace safety and health committees. Rogers (1995, p. 388) describes the potential role of such mandated committees succinctly:

In principle, a system that lodges responsibility for monitoring compliance with health and safety committees, who should be better informed about problems than government inspectors, and that gives those committees some authority to address problems should enlist the knowledge of regulated actors in findings ways in particular settings of satisfying publicly determined standards. That is does so in a context of declared representation rights, moreover, mitigates use of costly litigation.

As suggested by this quote, workplace committees conceivably fulfill the two roles for a workplace intermediary for implementing labor policies. First, by being mandated by the government (rather than voluntarily adopted by employers) the committee can serve as an agent of employees at the workplace. In this way, it has an intrinsic interest in vertically aggregating preferences for the public goods created by workplace regulations. Second, a well functioning committee can provide information on worker rights, workplace conditions, and administrative procedures, thereby lowering $\mathrm{MC}_{j}$. Finally, a workplace committee might also provide a protective shield for individual workers who might be more inclined to report problems before, during, or after inspections than they would in the absence of such committees. As a result, mandating committee structures potentially fulfill the major roles described above. 
The primary question in evaluating workplace committees concerns whether mandated committees function effectively. One major concern comes back to the agency problem: If workers view the committee primarily as a creature of the employer, the nature of the agency relation between the committee and workers is weakened, and it will be less effective in its public goods provision role, as well as in lowering the perceived costs arising from discrimination. A second question concerns its capacities to undertake activities effectively (even if it functions independently of the employer). This will affect its ability to appreciably lower the marginal costs of exercising rights.

The experience of mandated health and safety committee in the state of Oregon provide one indication of the determinants of their effectiveness. Weil (1999) examines the impact of committee mandates on the union effect on OSHA enforcement. Comparing OSHA inspection outcomes for two years preceding and following implementation of committee mandates, he finds that mandated committees significantly increase the differential between union and nonunion enforcement, arising from considerable strengthening of enforcement activity in union workplaces and only modest increases in enforcement in nonunion workplaces. The only exception to this is in the case of large nonunion establishments where committees have more appreciable impacts on enforcement activity.

The results suggest that mandated committees do not represent a simple solution to the problem of finding alternative workplace institutions to help implement labor policies. Effectiveness in filling the roles laid out in Figure 1 is a function of at least two factors. First, the regulations mandating committees in the first place must allow the establishment of independent workplace structures. Safety and health committee mandates vary enormously in terms of their delegated roles, authority, and the methods in which they are established (see 
Bernard (1995); Reilly, Paci, and Holl (1995); Rogers (1995); U.S. GAO (1992)). Second, committee effectiveness is related to antecedent conditions in the workplace itself, in particular characteristics of workforce that affect committees' capacity to take on its activities as well as its ability to function independently. In addition to the size of the workplace, factors might include worker turnover, skill and education level, and factors affecting informal worker organization.

\section{IIIE. Third Party Monitors}

In recent years, the use of third party monitors as regulatory agents has been discussed as a possible solution to limited government enforcement resources. Proposals for the use of third party monitors (such as accounting firms) in the area of safety and health gained public attention and became the subject of criticism when it appeared as part of Vice President Al Gore's "Reinventing Government" proposals for the federal sector.

In more recent years, third party monitors have been used as part of innovative efforts for enforcing the Fair Labor Standards Act provisions on minimum wage and overtime in the U.S. apparel industry. In particular, the Department of Labor has secured agreement by apparel manufacturers to use third parties to monitor aspects of compliance with the FLSA as part of larger settlement agreements with the Department. The role of these monitors is to be able to conduct surprise inspections on behalf of the manufacturer among subcontractors used by the manufacturer. The results of the inspections can be used by the manufacturer to monitor cases where non-compliant contractors are violating the Act, thereby exposing the manufacturer to civil penalties and more importantly supply disruptions (U.S. Department of Labor 1999).

Monitors can either be drawn from the private sector (accounting firms; for-profit enterprises specifically created for this function) or the not-for-profit sector (that is, independent 
organizations that created to act as workplace monitors). In the case of monitors created under "Compliance Program Agreements" between the U.S. Department of Labor and apparel manufacturers, their structure, funding, and activities are negotiable, although the Labor Department has "model provisions" that it encourages manufacturers to adopt (U.S. Department of Labor 1998).

The agency relations of third party monitors are complex in that-at least on paper--they act as agents of government. However, in reality they are agents of other private parties who have an interest in allowing them to take on certain quasi-governmental activity. In the area of apparel, third party monitors are usually the agents of manufacturers who use them to monitor their subcontractors in terms of compliance with minimum wage and overtime laws required by FLSA. Manufacturers have the incentive to agree to use such outside monitors to ensure that their sewing contractors comply with labor standards because of concern that noncompliance with laws can lead their goods to be embargoed by the Department of Labor. Resulting delays in shipments to retailers can have costly consequences to the manufacturer (Weil 2000). As a result, the interests of third party monitors, though agents of the manufacturer, are also aligned to some extent with those of the government. ${ }^{14}$

Third party monitors, then, may help deal with the threshold gap depicted in Figure 1 more in their capacity to supplement the enforcement activities of the Department of Labor, than in their potential role as an institutional agent for workers. Although the presence of a third party monitor raises the probability that a given workplace will be inspected, and that workers might have an opportunity to report problems, the threshold problem is much the same as under the traditional regulatory system. Monitors may, however, lower the marginal cost associated with worker exercise of rights, particularly if they provide a "shield" against discrimination if 
workers bring labor standards violations to their attention. The degree to which they play this role has in large part to do with the specific monitoring protocols negotiated between manufacturers, monitors, and the government. Examining how different types of protocols affect the exercise of rights and implementation of regulations presents an important area for future study.

IIIF. Alternative dispute resolution systems

On the surface, alternative dispute resolution (ADR) systems may not seem to fit the description of an emerging labor market institution, in that ADR describes a process of resolving disputes arising under workplace regulation rather than being a workplace entity per se. ADR has been used in a variety of forums, but is discussed here in its specific use as a means for resolving employment disputes arising under labor statutes through mediation, arbitration, or some combination of the two (for an overview of the use of ADR in this capacity and others, see Dunlop and Zack 1997, 2001).

Under ADR, an employee seeks recourse to a problem such as discrimination via an internal mediation / arbitration procedure rather than through the relevant agency or via the courts. Because these procedures are administered within the company and rely, at least at initial stages, on mediation, disputes can in theory be resolved more rapidly.

Two major Supreme Court decisions, the Gilmer decision of 1991 and the Circuit City in 2001 raise the stakes of ADR as a means of resolving such claims. ${ }^{15}$ Both Gilmer and Circuit City extend the Federal Arbitration Act from its historic focus on commercial disputes to those involving employment contracts. Specifically, they support the right of an employer to require employees to sign pre-hire agreements compelling them to use company-sponsored dispute 
resolution (usually arbitration) for statutory disputes rather than using the administrative channels established in the legislation (as described in Table 1). In effect, employees forgo their right to pursue such claims through administrative channels as a condition of employment.

Not surprisingly, the Gilmer and Circuit City decisions are controversial, most notably because of doubts that employees will receive a fair hearing in company-sponsored arbitration systems. In fact, many companies in the immediate wake of Gilmer adopted arbitration procedures that were decidedly tilted towards the employer in that companies unilaterally chose the arbitrator, established rules of the procedure (including barring formal depositions or even written records of the arbitration), and held the right to unilaterally change those procedures. In response to the employer bias of many post-Gilmer ADR systems, a number of the institutions drawn upon by companies to serve in arbitration proceedings (including the American Association of Arbitrators and the American Bar Associations) created a "Due Process Protocol" which establishes that signatory associations and their members will only serve as arbitrators in systems that adhere to basic conditions of procedural fairness. ${ }^{16}$

Even assuming that the "Due Process Protocol" assures a modicum of fairness in such proceedings in nonunion workplaces, does establishing internal procedures for mediation and / or arbitration of statutory disputes provide a solution to the rights problem portrayed in Figure 1? On one hand, ADR can be seen as a means of lowering the marginal cost of exercise of rights in that it makes (potentially) the cost for the disputant lower than under the traditional system where workers must press their own claims under various federal labor statutes. By lowering the costs of exercise, the gap depicted in Figure 1 narrows.

On the other hand, the use of ADR by parties in nonunion workplaces still presupposes that an employee comes forward with a claim. Yet the exis tence of an internal procedure (and 
the requirement to use that system via pre-hire agreement) does not inherently create an agent for those employees. ${ }^{17}$ The fact that the procedure is governed by the employer rather than a third party (i.e. the government) may further dampen the extent to which workers collectively might pursue a claim involving more widespread violations of a statutory right.

As a result, ADR may be most beneficial in those cases where the divergence between individual and workplace marginal benefits is relatively small, such as in resolving disputes arising under workers compensation or very specific claims under statutes like FLSA or ERISA. But in most areas of workplace regulation—-particularly regarding workplace discrimination that has motivated many nonunion companies to adopt internal arbitration systems ${ }^{18}$ - ADR does not provide a solution to the public goods problem. It remains to be seen if the growth of ADR potentially fueled by the Circuit City decision will induce existing institutions (e.g. labor unions, workers' rights groups, law firms) to serve a new role as third party representatives within nonunion firms.

\section{Concluding Thoughts and Implications}

It is easy for politicians, or reformers, or trade union officials to boast of the laws which they have secured for labor, and it is just as easy to overlook the details, or appropriations, or competent officials that are needed to make them enforceable. (Commons and Andrews 1936, p. 448).

Can emerging labor market institutions play the role of collective agent in a workplace that draws heavily upon the exercise of individual rights for implementation? Are there emerging labor market institutions that plausibly can take up this role where labor unions are not present? 
Table 3 summarizes the analysis of the ability of alternative workplace institutions surveyed above to do so. An implication of the foregoing analysis is that it may be difficult for a single institution to play the varied roles required of a collective agent across a range of workplace regulations. In particular, absent a labor union, it is difficult to devise an institutional arrangement that effectively aligns its interests with those of the workforce and at the same time has the kind of access to the workplace necessary to act upon those interests. Nonetheless, Table 3 suggests that a mixed approach, incorporating different institutions for different areas of regulation might help to close the gap arising in implementation of workplace regulations. Posed in this way, the policy question shifts from a focus on the agent per se and to the functions that must be performed to assure that the objectives of workplace regulations are achieved. For example, one set of policy options revolves around reducing the marginal cost of exercise of rights. This might include finding new means of making workers aware of their statutory rights or reducing the perceived cost of exercise by improving protections against employer discrimination (e.g. administrative procedures that protect employees' identity in the case of triggering inspections). Recent efforts by OSHA to create an extensive "workers' page" on their web site provides one example of interventions of this type. The page includes instructions on filing a complaint with OSHA (including downloadable complaint forms), information about statutory coverage, employee rights, and health and safety standards. ${ }^{19}$

Another range of policy options involves creating incentives to foster new workplace institutions that might provide some of the core functions of a collective agent. One approach would be to restructure aspects of regulatory systems to create incentives on the regulated parties themselves to fashion agents (such as private monitors) that provide at least some of the functions of collective agents. One example of this type of policy described above is the U.S. 
Department of Labor "No Sweat" enforcement strategy that induces manufacturers to create third party monitors to oversee the activities of subcontractors.

Alternatively, public policies might assist existing labor market institutions sharpen their abilities to undertake the central aspects as collective agents. Policy proposals in this vein include improving the access that public interest groups and other institutions have to employees at workplaces thereby enhancing their potential role as third party representatives in ADR systems. By improving employee access to potential outside representation, ADR systems (which will undoubtedly become even more prevalent in the wake of the Circuit City decision) will be better prepared to deal with systemic workplace problems. Developing a more robust set of institutions capable of representing nonunion workers in such company-based mediation and arbitration procedures may prove an important new means of improving the exercise of individual rights in nonunion workplaces.

Commons and Andrews recognized at the dawn of the modern era of workplace regulation that enactment of labor regulations did not assure implementation. Along with guaranteeing that the agencies vested with enforcement or administrative authority receive adequate appropriations and are staffed with competent personnel, this essay underscores the need to develop complementary institutions in the labor market to assure full implementation. Creating and fostering the institutions capable of taking on these functions may prove to be one of the most challenging aspects of regulating the labor market in the $21^{\text {st }}$ Century. 


\section{References}

Addison, John and McKinley Blackburn. 1994. "The Worker Adjustment and Retraining Notification Act: Effects on Notice Provision." Industrial and Labor Relations Review. Vol. 47, no.4 (July), pp. 650-662.

Bernard, Elaine. 1995. "Canada: Joint Committees on Occupational Safety and Health.” Works Councils: Consultation, Representation, and Cooperation in Industrial Relations, eds. Joel Rogers and Wolfgang Streeck, 351-374, Chicago, IL: University of Chicago Press.

Blank, Rebecca and David Card. 1991. "Recent Trends in Insured and Uninsured Employment: Is There an Explanation?" Quarterly Journal of Economics, Vol. , pp. 1157-1189.

Budd, John and Angela Brey. 2000. "Unions and Family Leave: Early Experience under the Family Medical Leave Act.” Unpublished manuscript. University of Minnesota.

Budd, John and Brian McCall. 1997. "The Effect of Unions on the Receipt of Unemployment Insurance Benefits." Industrial and Labor Relations Review, Vol. 50, no.3, pp. 478-492.

Bureau of National Affairs. 1997. Basic Patterns in Union Contracts, 16th edition. Washington D.C.: Bureau of National Affairs.

Butler, Richard and John Worrall. 1983. “Workers' Compensation: Benefit and Injury Claims Rates in the Seventies." The Review of Economics and Statistics, Vol. 65, pp. 580-589. 
Commission on the Future of Worker-Management Relations. 1994. Fact Finding Report. Washington, D.C.

Commons, John R. and John Andrews. 1936. Principles of Labor Legislation. $4^{\text {th }}$ edition. New York: Augustus M. Kelley, Reprints of Economic Classics.

Dunlop, John T. and Arnold Zack. 1997. Mediation and Arbitration of Employment Law Disputes. San Francisco: Jossey Bass.

. 2001. "Mediation of Statutory Enforcement Disputes." Manuscript, Harvard University.

Ehrenberg, Ronald and George Jakubson. 1990. "Why WARN? Plant Closing Legislation." Cato Review of Business and Government, Summer, pp. 39-42.

Ehrenberg, Ronald, and Paul Schumann. 1982. Longer Hours or More Jobs? An Investigation of Amending Hours Legislation to Create Employment. Ithaca, NY: ILR Press.

Elliott, Kimberly and Richard Freeman. 2000. "White Hats or Don Quixotes? Human Rights Vigilantes in the Global Economy." Paper presented at the NBER / Conference on Emerging Labor Market Institutions for the $21^{\text {st }}$ Century, Cambridge, MA. 
Freeman, Richard. 1985. "Unions, Pensions, and Union Pension Funds", in David Wise, ed., Pensions, Labor and Individual Choice. Chicago: University of Chicago Press.

Freeman Richard and James Medoff. 1984. What Do Unions Do? New York: Basic Books.

Freeman Richard and Joel Rogers. 1999. What Workers Want. Ithaca, NY: ILR Press.

Gleason, Sandra and Karen Roberts. 1993. "Worker Perceptions of Procedural Justice in Workers' Compensation Claims: Do Unions Make a Difference?" Journal of Labor Studies Vol. 14 , no. 1 , pp. $45-58$.

Hersch, Joni. 2000. “Time for an Employees' Lobby?” Paper presented at the NBER / Conference on Emerging Labor Market Institutions for the $21^{\text {st }}$ Century, Cambridge, MA.

Hirsch, Barry, David Macpherson, and Michael DuMond. 1997. "Workers' Compensation Recipiency in Union and Nonunion Workplaces." Industrial and Labor Relations Review, Vol. 50, pp. 213-236.

Hoerr, John. 1988 And the Wolf Finally Came: The Decline of the American Steel Industry. (Pittsburgh, PA: University of Pittsburgh Press).

Hoyman, Michele and Lamont Stallworth. 1981. "Who Files Suits and Why: An Empirical Portrait of the Litigious Worker." University of Illinois Law Review. Vol. 198, no. 1, pp.115-159. 
Jolls, Christine. 2000. "The Role and Functioning of Public-Interest Legal Organizations in the Enforcement of Employment Laws." Paper presented at the NBER / Conference on Emerging Labor Market Institutions for the $21^{\text {st }}$ Century, Cambridge, MA.

Langbert, Mitchell. 1995. "Voice Asymmetries in ERISA Litigation." Journal of Labor Research, Vol. 16, pp. 145-174.

Leonard, Jonathon. 1985. "The Effect of Unions on the Employment of Blacks, Hispanics, and Women "Industrial and Labor Relations Review, Vol. 39, No. 1 (October), pp. 115-132.

Masters, Marick. 1997. Unions at the Crossroads: Strategic Membership, Financial, and Political Perspectives. Westport, CT: Quorum.

McAteer, Davitt. 1985. Miner's Manual. (West Virginia: Keystone Publishers).

Reilly, Barry, Pierella Paci, and Peter Holl. 1995. "Unions, Safety Committees and Workplace Injuries." British Journal of Industrial Relations, Vol. 33, No. 2 (June), pp. 275-288.

Rogers, Joel. 1995. "United States: Lessons from Abroad and Home.” In Works Councils: Consultation, Representation, and Cooperation in Industrial Relations, eds. Joel Rogers and Wolfgang Streeck, 375-419, Chicago, IL: University of Chicago Press. 
Samuelson, Paul. 1955. "Diagrammatic Exposition of a Theory of Public Expenditure." Review of Economics and Statistics, Vol. 37, pp. 350-356.

Stern, Robert and Deborah Balser. 1996. "Regulations, Social Control, and Institutional Perspectives: Implementing the Americans with Disabilities Act." Unpublished manuscript, Cornell University.

Stigler, George. 1974. "Free Riders and Collective Action.” Bell Journal of Economics, Vol. 5, pp. 359-365.

Trejo, Stephen. 1991. "The Effects of Overtime Pay Regulation on Worker Compensation." American Economic Review Vol. 81, no.4, pp. 719-740.

U.S. Department of Labor. 1998. "Full Hot Goods Compliance Program Agreement.” DOL Form FCPA(AB).CP1. Washington, D.C.: Wage and Hour Division, U.S. Department of Labor. . 1999. "Protecting America's Garment Workers: A Monitoring Guide."

Washington, D.C.: U.S. DOL.

U.S. Government Accounting Office. 1989. How Well Does OSHA Protect Workers from Reprisals: Inspector Opinions. GAO/T-HRD-90-8. 
1992. Occupational Safety and Health: Worksite Safety and Health Committees

Show Promise. GAO/HRD-92-68.

1994. Workplace Regulation: Information on Selected Employer and Union

Experiences. GAO/HEHS-94-138.

. 2000. Worker Protection: OSHA Inspections at Establishments Experiencing

Labor Unrest. GAO/HEHS-00-144.

Viscusi, W. Kip. 1983. Risk by Choice: Regulating Health and Safety in the Workplace.

Cambridge, MA: Harvard University Press.

Viscusi, W. Kip. and Charles O'Connor. 1984. "Adaptive Responses to Chemical Labeling: Are Workers Bayesian Decision Makers?" American Economic Review Vol. 74, no.5, pp. 942-956.

Wandner, Stephen and Andrew Skinner. 2000. "Why Are Many Jobless Workers Not Applying for Benefits?” Monthly Labor Review, Vol. 123 (June), pp. 21-32.

Weil, David. 1990. "Protecting the Mine Face: The United Mine Workers and the Enforcement of the Mine Health and Safety Act.” Unpublished manuscript. Boston University.

1991. "Enforcing OSHA: The Role of Labor Unions." Industrial Relations.

Vol.30, no.1 (Winter), pp. 20-36. 
. 1992. "Building Safety: The Role of Construction Unions in the Enforcement of OSHA." Journal of Labor Research, Vol.13, no. 1 (Winter), pp.121-132. . 1996. "If OSHA Is So Bad, Why Is Compliance Go Good?" The RAND

Journal of Economics, Vol. 27, no. 3 (Autumn), pp. 618-640.

. 1999. "Are Mandated Health and Safety Committees Substitutes or

Supplements to Labor Unions?" Industrial and Labor Relations Review Vol.52, (April), pp.339360.

. 2000. "Everything Old is New Again: Regulating Labor Standards in the U.S. Apparel Industry." $52^{\text {nd }}$ Annual Proceedings of the Industrial Relations Research Association, (Champaign, IL: IRRA), pp. 146-155.

Williamson, Oliver. 1985. The Economic Institutions of Capitalism. New York: The Free Press. 

Table 1: Employee Rights and Reporting Requirements under Federal Workplace Regulations

\begin{tabular}{|c|c|c|c|c|c|c|c|}
\hline \multirow{2}{*}{$\begin{array}{l}\text { Labor Statute or } \\
\text { Executive Order }^{\mathrm{a}}\end{array}$} & \multicolumn{3}{|c|}{ Designated Employee Rights } & \multicolumn{4}{|c|}{ Reporting / Disclosure Requirements } \\
\hline & $\begin{array}{l}\text { Employee right to } \\
\text { initiate agency } \\
\text { action }\end{array}$ & $\begin{array}{l}\text { Private right of } \\
\text { action available } \\
\text { to employee a }\end{array}$ & $\begin{array}{l}\text { Private right of } \\
\text { action, after } \\
\text { exhaustion of } \\
\text { administrative } \\
\text { remedies }\end{array}$ & $\begin{array}{c}\text { Forms } \\
\text { completed or } \\
\text { filed w/ agency }\end{array}$ & $\begin{array}{l}\text { Payroll / other } \\
\text { business data } \\
\text { must be collected }\end{array}$ & $\begin{array}{l}\text { Notices must } \\
\text { be posted in } \\
\text { workplace }\end{array}$ & $\begin{array}{l}\text { Data on } \\
\text { injuries and } \\
\text { complaints } \\
\text { reported }\end{array}$ \\
\hline \multicolumn{8}{|l|}{ Labor Standards } \\
\hline FLSA & $\checkmark$ & $\checkmark$ & & & $\checkmark$ & $\checkmark$ & \\
\hline Davis-Bacon Act & $\checkmark$ & $\checkmark$ & & $\checkmark$ & $\checkmark$ & $\checkmark$ & \\
\hline SCA & & & & & $\checkmark$ & $\checkmark$ & \\
\hline Walsh-Healy Act & & & & & $\checkmark$ & $\checkmark$ & \\
\hline CWHSSA & & $\checkmark$ & & $\checkmark$ & $\checkmark$ & & \\
\hline MSPA & & $\checkmark$ & $\checkmark$ & $\checkmark$ & $\checkmark$ & $\checkmark$ & \\
\hline \multicolumn{8}{|l|}{ Benefits } \\
\hline ERISA & & $\checkmark$ & $\checkmark$ & $\checkmark$ & & $\checkmark$ & \\
\hline COBRA & & $\checkmark$ & $\checkmark$ & & & & \\
\hline $\begin{array}{l}\text { Unemployment } \\
\text { Compensation }\end{array}$ & & & & $\checkmark$ & $\checkmark$ & & \\
\hline FMLA & $\checkmark$ & $\checkmark$ & & & $\checkmark$ & $\checkmark$ & \\
\hline \multicolumn{8}{|l|}{ Civil Rights } \\
\hline Title VII & $\checkmark$ & $\checkmark$ & $\checkmark$ & $\checkmark$ & $\checkmark$ & $\checkmark$ & $\checkmark$ \\
\hline Equal Pay Act & $\checkmark$ & $\checkmark$ & & & $\checkmark$ & $\checkmark$ & $\checkmark$ \\
\hline EO 11246 & & & & $\checkmark$ & $\checkmark$ & $\checkmark$ & \\
\hline ADEA & $\checkmark$ & $\checkmark$ & & & $\checkmark$ & $\checkmark$ & $\checkmark$ \\
\hline
\end{tabular}




\begin{tabular}{|c|c|c|c|c|c|c|c|}
\hline$\overline{\mathrm{ADA}}$ & $\checkmark$ & $\checkmark$ & $\checkmark$ & & $\checkmark$ & $\checkmark$ & $\checkmark$ \\
\hline Rehabilitation Act & & & & & & $\checkmark$ & $\checkmark$ \\
\hline \multicolumn{8}{|l|}{ STAA } \\
\hline \multicolumn{8}{|c|}{ Occupational Health \& Safety } \\
\hline OSHA & $\checkmark$ & & & $\checkmark$ & & $\checkmark$ & $\checkmark$ \\
\hline MSHA & $\checkmark$ & & & $\checkmark$ & & $\checkmark$ & $\checkmark$ \\
\hline DFWA & & & & $\checkmark$ & & $\checkmark$ & $\checkmark$ \\
\hline \multicolumn{8}{|l|}{ Labor Relations } \\
\hline NLRA & & $\checkmark$ & & & & $\checkmark$ & \\
\hline LMRDA & & $\checkmark$ & & $\checkmark$ & & & \\
\hline RLA & & & & & & $\checkmark$ & \\
\hline \multicolumn{8}{|c|}{ Hiring \& Separation Decisions } \\
\hline PPA & & $\checkmark$ & & $\checkmark$ & & $\checkmark$ & \\
\hline $\begin{array}{l}\text { Veterans Re-employment } \\
\text { Act }\end{array}$ & & $\checkmark$ & & & $\checkmark$ & & \\
\hline IRCA & & $\checkmark$ & & $\checkmark$ & & $\checkmark$ & \\
\hline WARN & & $\checkmark$ & & & & $\checkmark$ & \\
\hline
\end{tabular}

${ }^{\mathrm{a}}$ Full names of statutes, date of passage, and brief description provided in Appendix Table A1. 


\section{TABLE 2: Impact of Labor Unions on Enforcement and Compliance with Workplace Regulations}

\begin{tabular}{|c|c|c|c|}
\hline $\begin{array}{l}\text { Labor Statute or } \\
\text { Executive Order }\end{array}$ & Union Impact on Enforcement & $\begin{array}{l}\text { Union Impact on Employer } \\
\text { Compliance }\end{array}$ & Study \\
\hline $\begin{array}{l}\text { Fair Labor Standards Act - } \\
\text { Overtime Provisions }\end{array}$ & $\begin{array}{l}\text { Inclusion of premium pay for overtime standard } \\
\text { in collective agreements }\end{array}$ & $\begin{array}{l}\text { Increase the probability of compliance for } \\
\text { unionized workers }\end{array}$ & $\begin{array}{l}\text { Enforcement: } \\
\text { BNA (1997) } \\
\text { Compliance: } \\
\text { Ehrenberg and Schumann (1982); } \\
\text { Trejo (1991) }\end{array}$ \\
\hline ERISA & $\begin{array}{l}\text { Raise degree of scrutiny over eligible pension } \\
\text { plans }\end{array}$ & $\begin{array}{l}\text { Require more strict adherence to } \\
\text { eligibility and financial management } \\
\text { standards by employers }\end{array}$ & $\begin{array}{l}\text { Enforcement: } \\
\text { Langbert (1995) } \\
\text { Compliance: } \\
\text { Freeman (1985) }\end{array}$ \\
\hline OSHA & $\begin{array}{l}\text { Higher inspection probabilities; longer } \\
\text { inspections; shorter abatement duration; and } \\
\text { higher penalties }\end{array}$ & $\begin{array}{l}\text { Higher rates of compliance with specific } \\
\text { OSHA standards }\end{array}$ & $\begin{array}{l}\text { Enforcement: } \\
\text { Weil (1991, 1992) } \\
\text { Compliance: } \\
\text { Weil (1996) }\end{array}$ \\
\hline MSHA & $\begin{array}{l}\text { Higher inspection probabilities; longer / more } \\
\text { intense inspections; shorter abatement duration; } \\
\text { higher penalties }\end{array}$ & N/A & Weil (1990) \\
\hline EO 11246 & $\begin{array}{l}\text { No impact on probability of receiving a federal } \\
\text { contract compliance review }\end{array}$ & N/A & Leonard (1985) \\
\hline WARN & $\begin{array}{l}\text { Increase in the probability of filing suit under } \\
\text { WARN }\end{array}$ & $\begin{array}{l}\text { No impact on the probability of providing } \\
\text { advance notice to affected workers }\end{array}$ & $\begin{array}{l}\text { Enforcement: } \\
\text { GAO (1993); } \\
\text { Ehrenberg and Jakubson (1990) } \\
\text { Compliance: } \\
\text { Addison and Blackburn (1994) }\end{array}$ \\
\hline$\overline{\mathrm{ADA}}$ & N/A & $\begin{array}{l}\text { Raise probability that firms comply with } \\
\text { four core practices required by ADA }\end{array}$ & Stern and Balser (1996) \\
\hline FMLA & $\begin{array}{l}\text { Improve information to workers regarding } \\
\text { rights and eligibility under FMLA }\end{array}$ & $\begin{array}{l}\text { Increase probability that leave was fully } \\
\text { paid by employer as provided }\end{array}$ & Budd and Brey (2000) \\
\hline Workers Compensation & N/A & $\begin{array}{l}\text { Increase probability of filings for benefits } \\
\text { among eligible workers and benefit levels } \\
\text { for given disability level. }\end{array}$ & $\begin{array}{l}\text { Butler and Worrall (1983) } \\
\text { Hirsch, Macpherson, \& DuMond (1997) }\end{array}$ \\
\hline Unemployment Compensation & N/A & $\begin{array}{l}\text { Increase in the probability of filing for } \\
\text { benefits among eligible workers }\end{array}$ & $\begin{array}{l}\text { Blank and Card (1991) } \\
\text { Budd and McCall (1997) }\end{array}$ \\
\hline
\end{tabular}


Table 3: Evaluation of alternative labor market institutions in implementing labor market policies

\begin{tabular}{|c|c|c|c|c|}
\hline $\begin{array}{l}\text { Labor market } \\
\text { institution }\end{array}$ & $\begin{array}{l}\text { Address the } \\
\text { public goods } \\
\text { problem? }\end{array}$ & $\begin{array}{l}\text { Lower } \\
\text { marginal } \\
\text { cost of } \\
\text { exercise of } \\
\text { rights? }\end{array}$ & $\begin{array}{c}\text { Protect } \\
\text { against } \\
\text { worker } \\
\text { discrimination } \\
?\end{array}$ & $\begin{array}{l}\text { Comments on } \\
\text { effectiveness of } \\
\text { workplace } \\
\text { institution }\end{array}$ \\
\hline Labor unions (Benchmark) & Yes & Yes & Yes & $\begin{array}{l}\text { See table } 2 \text { for } \\
\text { empirical results }\end{array}$ \\
\hline National issue organizations & No & No & No & $\begin{array}{l}\text { Agency problems } \\
\text { limit role to } \\
\text { precedent setting } \\
\text { cases } \\
\end{array}$ \\
\hline Legal service organizations & No & Partially & No & $\begin{array}{l}\text { Agency problems } \\
\text { limit role to } \\
\text { individual } \\
\text { advocacy }\end{array}$ \\
\hline $\begin{array}{l}\text { Other public interest } \\
\text { organizations (e.g. COSH / } \\
\text { Disabled workers advocacy } \\
\text { organizations) }\end{array}$ & No & Yes & Partially & $\begin{array}{l}\text { Largest impact in } \\
\text { assisting workers } \\
\text { in receiving } \\
\text { benefits (e.g. } \\
\text { workers } \\
\text { compensation) }\end{array}$ \\
\hline $\begin{array}{l}\text { Mandated workplace } \\
\text { committees }\end{array}$ & Yes / No & Yes & Yes / No & $\begin{array}{l}\text { Effectiveness is } \\
\text { function of nature } \\
\text { of the mandate } \\
\text { and antecedent } \\
\text { conditions in the } \\
\text { workplace (e.g. } \\
\text { size; workforce } \\
\text { turnover) } \\
\end{array}$ \\
\hline $\begin{array}{l}\text { Third party monitors (e.g. } \\
\text { FLSA) }\end{array}$ & $?$ & Yes & Partially & $\begin{array}{l}\text { Monitors' agency } \\
\text { relationship with } \\
\text { third party and } \\
\text { government } \\
\text { creates a role as } \\
\text { supplementary } \\
\text { enforcement } \\
\text { resource } \\
\end{array}$ \\
\hline $\begin{array}{l}\text { Alternative Dispute Resolution } \\
\text { systems }\end{array}$ & No & Yes & $?$ & $\begin{array}{l}\text { Most effective } \\
\text { where divergence } \\
\text { of private and } \\
\text { workplace } \\
\text { benefits from } \\
\text { exercise of rights } \\
\text { is small. } \\
\end{array}$ \\
\hline
\end{tabular}


Figure 1

Threshold Model of Employee Exercise of Rights

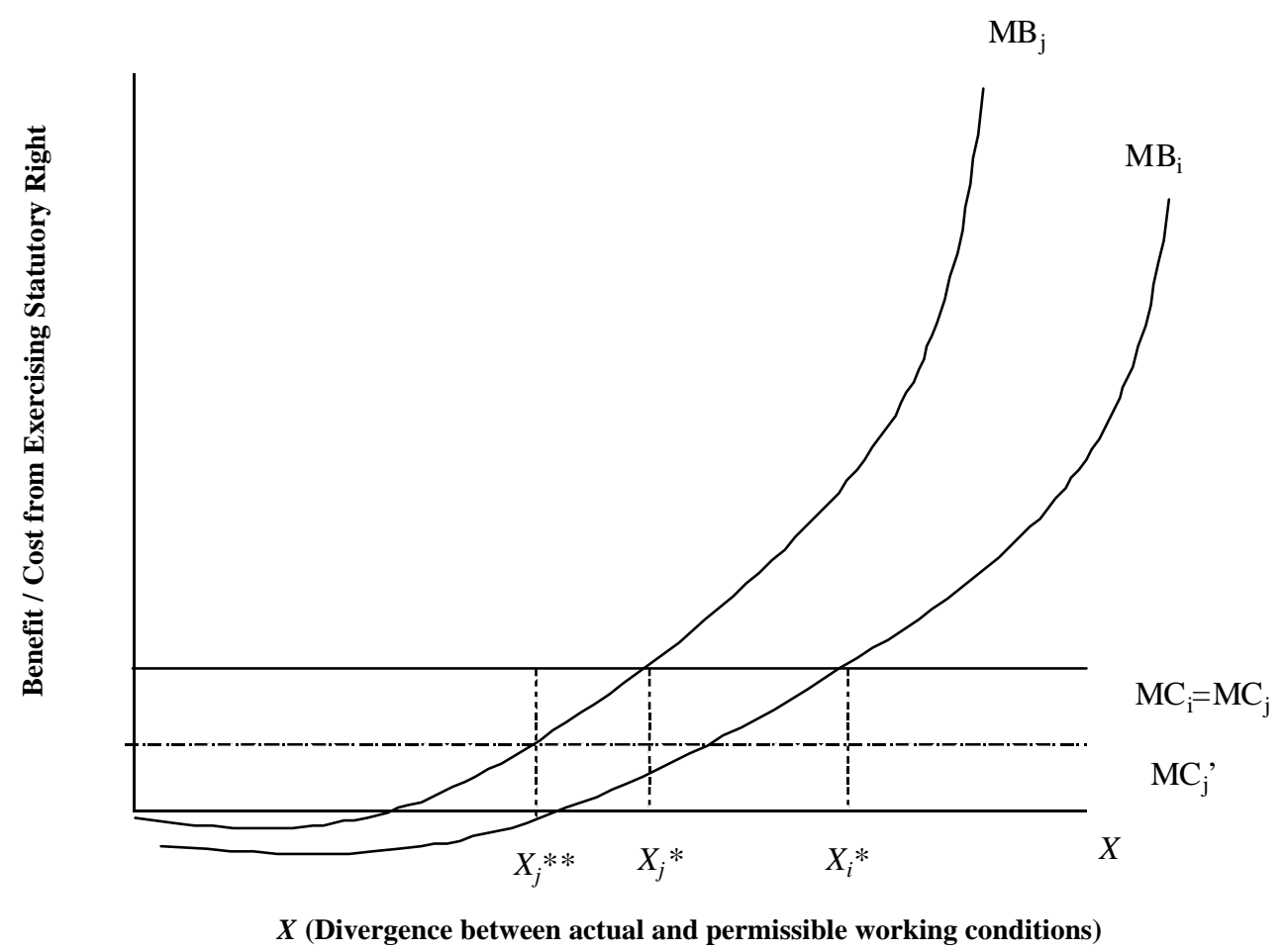


Table A1: Major Federal Workplace Regulations

\begin{tabular}{|c|c|c|c|}
\hline Labor Statute or Executive Order & Acronym & $\begin{array}{l}\text { Date of } \\
\text { Passage }\end{array}$ & Description \\
\hline \multicolumn{4}{|l|}{ Labor Standards } \\
\hline Fair Labor Standards Act & FLSA & 1938 & Establishes minimum wage, overtime pay and child labor standards \\
\hline Davis-Bacon Act & -- & 1931 & $\begin{array}{l}\text { Provides for payment of prevailing local wages and benefits to workers employed by contractors and subcontractors on } \\
\text { federal contracts for construction, alteration, repair, painting or decorating of public buildings or public works }\end{array}$ \\
\hline Service Contract Act & SCA & 1963 & $\begin{array}{l}\text { Provides for payment of prevailing local wages and fringe benefits and safety \& health standards for employees of } \\
\text { contractors and subcontractors providing services under federal contracts }\end{array}$ \\
\hline Walsh-Healy Act & -- & 1936 & $\begin{array}{l}\text { Provides for labor standards including wage and hour, for employees working on federal contracts for the manufacturing or } \\
\text { furnishing of materials, supplies, articles, or equipment }\end{array}$ \\
\hline $\begin{array}{l}\text { Contract Work Hours and Safety } \\
\text { Standards Act }\end{array}$ & CWHSSA & 1962 & $\begin{array}{l}\text { Establishes standards for hours, overtime compensation, and safety for employees working on federal and federally funded } \\
\text { contracts and subcontracts }\end{array}$ \\
\hline $\begin{array}{l}\text { Migrant and Seasonal Agricultural } \\
\text { Workers Protection Act }\end{array}$ & MSPA & 1983 & $\begin{array}{l}\text { Protects migrant and seasonal agricultural workers in their dealings with farm labor contractors, agricultural employers, } \\
\text { associations, and providers of migrant housing }\end{array}$ \\
\hline \multicolumn{4}{|l|}{ Benefits } \\
\hline $\begin{array}{l}\text { Employee Retirement and Income } \\
\text { Security Act }\end{array}$ & ERISA & 1974 & $\begin{array}{l}\text { Establishes uniform standards for employee pension and welfare benefit plans, including minimum participation, accrual and } \\
\text { vesting requirements, fiduciary responsibilities, reporting and disclosure }\end{array}$ \\
\hline $\begin{array}{l}\text { Consolidated Omnibus Budget } \\
\text { Reconciliation Act }\end{array}$ & COBRA & 1986 & Provides for continued health care coverage under group health plans for qualified separated workers for up to 18 months \\
\hline $\begin{array}{l}\text { Unemployment Compensation provision } \\
\text { of the Social Security Act }\end{array}$ & -- & 1935 & $\begin{array}{l}\text { Authorizes funding for state unemployment compensation administrations and provides the general framework for the } \\
\text { operation of state unemployment insurance programs }\end{array}$ \\
\hline Family Medical Leave Act & FMLA & 1993 & $\begin{array}{l}\text { Entitles employees to take up to } 12 \text { weeks of unpaid, job-protected leave each for specified family and medical reasons such } \\
\text { as the birth or adoption of a child or an illness in the family }\end{array}$ \\
\hline \multicolumn{4}{|l|}{ Civil Rights } \\
\hline Title VII of the Civil Rights Act & -- & 1964 & $\begin{array}{l}\text { Prohibits employment or membership discrimination by employers, employment agencies, and unions on the basis of race, } \\
\text { color, religion, sex, or national origin; prohibits discrimination in employment against women affected by pregnancy, } \\
\text { childbirth, or related medical condition }\end{array}$ \\
\hline Equal Pay Act & -- & 1963 & Prohibits discrimination on the basis of sex in the payment of wages \\
\hline Executive Order 11246 & EO 11246 & 1962 & $\begin{array}{l}\text { Prohibits discrimination against an employee or applicant for employment by federal contractors, and requires federal } \\
\text { contractors to take affirmative action to ensure that employees and applicants for employment are treated without bias. }\end{array}$ \\
\hline
\end{tabular}




\begin{tabular}{|c|c|c|c|}
\hline Age Discrimination Employment Act & ADEA & 1967 & Prohibits employment discrimination on the basis of age against persons 40 years and older \\
\hline Americans with Disabilities Act & $\mathrm{ADA}$ & 1990 & $\begin{array}{l}\text { Prohibits employment discrimination against individuals with disabilities; requires employer to make "reasonable } \\
\text { accommodations" for disabilities unless doing so would cause undue hardship to the employer }\end{array}$ \\
\hline Rehabilitation Act (Section 503) & -- & 1973 & $\begin{array}{l}\text { Prohibits federal contractors and subcontractors from discriminating in employment on the basis of disability and requires } \\
\text { them to take affirmative action to employ, and advance in employment, individuals with disabilities }\end{array}$ \\
\hline $\begin{array}{l}\text { Anti-retaliatory provision-Surface } \\
\text { Transportation Assistance Act }\end{array}$ & STAA & 1978 & $\begin{array}{l}\text { Prohibits the discharge or discriminatory action against employees for filing complaints relating to a violation of a } \\
\text { commercial motor vehicle safety rule or regulation or for refusing to operate a vehicle in violation of federal rules, or } \\
\text { because of a fear of serious injury due to an unsafe condition }\end{array}$ \\
\hline \multicolumn{4}{|l|}{ Occupational Health \& Safety } \\
\hline Occupational Safety \& Health Act & OSHA & 1970 & $\begin{array}{l}\text { Requires employers to furnish each employee with work and a workplace free from recognized hazards that can cause death } \\
\text { or serious physical harm }\end{array}$ \\
\hline Federal Mine Safety \& Health Act & MSHA & 1969 & Requires mine operators to comply with health and safety standards and requirements established to protect miners \\
\hline Drug Free Workplace Act & DFWA & 1988 & Requires recipients of federal grants and contracts to take certain steps to maintain a drug free workplace \\
\hline \multicolumn{4}{|l|}{ Labor Relations } \\
\hline National Labor Relations Act & NLRA & 1935 & $\begin{array}{l}\text { Protects certain rights of workers including the right to organize and bargain collectively through representation of their own } \\
\text { choice }\end{array}$ \\
\hline $\begin{array}{l}\text { Labor-Management Reporting \& } \\
\text { Disclosure Act }\end{array}$ & LMRDA & 1959 & $\begin{array}{l}\text { Requires the reporting and disclosure of certain financial and administrative practices of labor organizations and employers; } \\
\text { establishes certain rights for members and imposes other requirements on labor organizations }\end{array}$ \\
\hline Railway Labor Act & RLA & 1926 & $\begin{array}{l}\text { Sets out the rights and responsibilities of management and workers in the rail and airline industries and provides for } \\
\text { negotiation and mediation procedures to settle labor-management disputes }\end{array}$ \\
\hline \multicolumn{4}{|l|}{ Hiring \& Separation Decisions } \\
\hline Employee Polygraph Protection Act & PPA & 1988 & Prohibits the use of lie detectorsfor pre-employment screening or use during the course of employment \\
\hline Veterans' Reemployment Rights Act & VRR & 1940 & Provides reemployment rights for persons returning from active duty, reserve training, or National Guard duty \\
\hline $\begin{array}{l}\text { Immigration Reform \& Control Act } \\
\text { (Employment provisions) }\end{array}$ & IRCA & 1986 & $\begin{array}{l}\text { Prohibits the hiring of illegal aliens and imposes certain duties on employers; protects employment rights of legal aliens; } \\
\text { authorizes but limits the use of imported temporary agricultural workers }\end{array}$ \\
\hline Workers Adjustment \& Retraining Act & WARN & 1988 & $\begin{array}{l}\text { Requires employers to provide } 60 \text { days advance written notice of a layoff to individual affected employees, local } \\
\text { governments, and other parties }\end{array}$ \\
\hline
\end{tabular}





\section{Endnotes}

${ }^{1}$ For example, Stigler (1974) explains the significant influence of certain small interest groups arises from their ability to surmount the free rider problem among supporters as a result of their potentially high payoff from political action and the ability of members of the coalition to sanction non-participants. In this view, an employment lobby representing individual workers faces a far greater problem of funding its political activities because of the more diffuse benefits conferred to individual workers arising from supporting the lobby's agenda and the difficulty of denying benefits or instituting sanctions because of non-participation. Unions address this free rider problem by allocating a portion of dues revenues to political activities directed towards workplace issues (see Masters 1997 for a recent discussion). Whether other institutions can play a comparable role is discussed in Hersch (2000).

2 This can be seen in the relative growth in five categories of employment related lawsuits filed in federal district courts between 1971 and 1991. The fastest growing category in relative terms over the period has been litigation on employment law, which went in absolute terms from 4,331 cases filed in 1971 to 22,968 cases in 1991 . As a result, employment law went from comprising about $6 \%$ of the 69,465 civil cases filed in federal district courts in 1971 to about $16 \%$ of the 146,790 civil cases filed in 1991 . These figures are reported in Commission on the Future of Worker-Management Relations (1994), Exhibit IV-3, p. 134.

${ }^{3}$ This is a recurring problem under workplace regulation. For example, a survey of OSHA compliance officers by the GAO concluded that "...many OSHA inspectors believe workers' participation [in OSHA] is limited by their lack of knowledge about 
their rights and lack of protection from employer reprisal" (U.S. GAO 1989). The decline in the "take up" rate for unemployment insurance has been partly ascribed to the lack of information to workers about their access to unemployment benefits (Wandner and Stettner 2000). Freeman and Rogers (1999, Chapter 6) also present survey evidence indicating pervasive worker misperceptions regarding their rights under employment and labor laws.

${ }^{4}$ The costs of retaliation may be even more severe, such as in the well-known 1996 case of apparel workers in El Monte, $\mathrm{Ca}$, held in virtual captivity by their employer who used physical intimidation to prevent the workers from leaving.

${ }^{5}$ The degree to which $\mathrm{MB}_{\mathrm{i}}$ diverges from $\mathrm{MB}_{\mathrm{j}}$ will differ across workplace regulations. For example, there are greater divergences between the functions for regulations like OSHA, FLSA, or policies dealing with discrimination where the risks or problems faced by one worker will likely be more pervasive and therefore affect many other workers as well. In contrast, under benefit programs like workers compensation or unemployment, the spill-overs are likely much smaller since the program primarily confers benefits to the worker directly affected. The implications of these differences are discussed in Section III.

${ }^{6}$ Strictly speaking, this third condition is really an aspect of the second condition. Discrimination for use of a right represents a cost to a worker arising from discipline or discharge.

${ }^{7}$ Williamson (1985: 254) points out, "(u)nions can both serve as a source of information regarding employee needs and preferences..." In addition to Williamson, the role of 
unions in providing basic agency functions is discussed in Freeman and Medoff (1984), particularly in regard to personnel practices and benefits.

${ }^{8}$ There might also be divergences in behavior arising from a number of sources. Median voter models of union behavior would predict that union leadership would tend to pursue policies reflective of more senior members of the unit which might not be synonymous with the public goods solution to benefit valuation. Alternatively, principal / agent divergences in interest may also lead away from optimal behaviors from the perspective of collective worker interests. For example, the union may have incentives to "overuse" certain rights for strategic reasons unrelated to the workplace regulation, for example as a source of pressure in collective bargaining or strikes (U.S. GAO 2000). However, principal / agent divergences in behavior may be moderated both through electoral processes and by worker recourse via duty of fair representation claims which tend to induce unions to pursue activities consonant with the preferences of represented workers. ${ }^{9}$ This latter effect of unions as workplace agents is particularly important given the long term decline in benefit recipiency under these programs (Wandner and Stettner 2000). ${ }^{10}$ Jolls cites a number of examples of Congress curtailing class action activity by legal service attorneys. The median voter hypothesis advanced here could be more rigorously tested by examining changes in legal service activities over time given shifts in political coalitions in Congress over time.

${ }^{11}$ This is not to argue that the alignment between these organizations and workers is as close as found in the case of labor unions. For example, donors to COSH or disabled worker groups may be similarly interested in "large impacts" as those funding national interest organizations which may skew institutional activities in a similar manner. The 
importance of union funds may also lead these organizations to direct their resources towards certain nonunion workplaces of strategic interest to unions. Even more, union funding could lead COSH groups to devote their resources supplementing the activities of unions in already organized workplaces. There is some evidence of the latter behavior, as described below.

${ }^{12}$ Indicative of this is the history of "New Directions" grants provided by OSHA in the 1970s and 1980s that provided financial assistance for promotion of private health and safety programs. The majority of these grants went either to unions or to joint $\mathrm{COSH} /$ union initiatives.

${ }^{13}$ Differences in the presence of worker groups to assist disabled workers versus unemployed workers once again raises the economics of interest group formation discussed by Stigler and others. The longevity of the effects of workplace disability as opposed to the transient nature of une mployment creates greater incentives for the formation of sustainable organizations concerning the former issue, and the difficulty of sustaining organizations (particularly over the course of business cycles) in the latter area. Thus, to the extent that workers groups have formed over the latter issue, they have been linked to industries facing periods of intense crisis (e.g. steel) or deep recessions. After crises pass (or industry restructuring occurs and workers find other employment) these groups tend to disband. See Hoerr (1988) for a discussion of these types of assistance groups in the steel industry.

${ }^{14}$ Where monitoring has been adopted out of strictly voluntary agreements and lacking the "teeth" of government sanctions like the right to embargo goods, the identification of third party monitors with regulatory objectives will be far weaker. This raises one of the 
limitations of using third party monitors in the international arena to police labor standards, where there is no comparable government authority underlying the agreements. Third party monitors in the international labor standards arena are discussed in Elliot and Freeman (2000).

${ }^{15}$ Gilmer v. Interstate / Johnson Lane Corp. 111 S. Ct. 1647 (1991); Circuit City Stores, Inc. v. Adams. 532 S. Ct __ (2001).

${ }^{16}$ Among those conditions, the Protocol specifies that the arbitration system provide employees with a right to representation in proceedings, and a right to participate in the selection of an arbitrator / mediator drawn from “...a demographically diverse panel of trained mediators and arbitrators..." (Dunlop and Zack, 2001, p. 6). The Due Process Protocol has been adopted by a wide variety of institutions drawn on by companies for arbitration.

${ }^{17}$ Note that this argument also supports the use of ADR in cases where some form of worker representative is already present, such as in unionized workplaces. Here, ADR can lead to more speedy and cost effective resolution of statutory disputes at the same time that workers' interests are protected through third party representation.

${ }^{18}$ The Gilmer case involved a case of age discrimination; Circuit City involved discrimination because of sexual preference.

${ }^{19}$ The "Workers' Page" can be found at http://www.osha.gov/as/opa/worker/index.html. 